\title{
onstage, the Online Data System of Theatre in Amsterdam from the Golden Age to Today
}

\section{Arts and Media}

\author{
Frans R. E. Blom \\ University of Amsterdam, Amsterdam, Netherlands \\ f.r.e.blom@uva.nl \\ Harm Nijboer \\ Huygens ING, Amsterdam, Netherlands \\ h.t.nijboer@uva.nl \\ Rob van der Zalm \\ University of Amsterdam, Amsterdam, Netherlands \\ r.g.c.vanderzalm@uva.nl
}

\begin{abstract}
ONSTAGE is the data repository for Amsterdam's first and most prominent public theatre venue: the Schouwburg. In theatre history, the Amsterdam Schouwburg has a fairly unique place due to its rich body of extant account books, programs and administrative records of annual play lists, and registers of expenses and revenues. These sources, as a most sensitive finger on the theatre's pulse, can be used as analytical tools that provide access to the theatre's artistic business, from its foundation in 1638 until today. This data paper is an assessment of the new ONSTAGE data system, in terms of its structure, the nature of the data and enrichment, and the research potential. The paper also explores future growth in linked data systems.
\end{abstract}

\section{Keywords}

history of theatre - Amsterdam Schouwburg - relational database - performance frequencies - popularity ranking 
- Related data set "ONSTAGE" with DoI https://www.doi.org/10.17026/dans -z37-2db7 in repository "DANs"

- See the showcase of the data in the Exhibit of Datasets: https://www.dans datajournal.nl/rdp/exhibit.html? showcase=blom2020

\section{Introduction}

ONSTAGE is the online data repository for Amsterdam's first and most prominent public theatre venue: the Schouwburg. In theatre history, the Amsterdam Schouwburg has a unique place due to its rich body of extant account books, programs and administrative records of annual play lists, and registers of expenses and revenues. These sources, as a most sensitive finger on the theatre's pulse, can be used as analytical tools that provide access to the theatre's artistic business from its foundation in 1638 until today.

Launched in 2015, ONSTAGE contains the theatre's program organized by date, supplemented with its revenues. ${ }^{1}$ As linked data, ONSTAGE is a key resource for performance details about any individual play in the Schouwburg. For each drama play, it holds information like the premiere date or its performance frequency per season. On a larger scale, ONSTAGE shows the plays' histories over time and their life cycles on stage from the premiere until the final performance. The linked data also generates statistics for playwright popularity, including peaks in specific years. Moreover, by compiling financial revenues per performance, the ONSTAGE data system can approximate the Schouwburg's occupation per performance and, thus, for the numbers of attendees.

Covering almost four centuries of performances and financial accounts, ONSTAGE can also be used to detect trends and shifting preferences. Quantification and longitudinal patterning open new telescopic perspectives into the theatre's history. Quantitative repertory research on popularity, shifting tastes and vogues challenges traditional conceptions about theatre fashion and preference. Until now, academic research into the theatre history of the Schouwburg has focused almost entirely on domestic plays by canonical playwrights such as Vondel, Hooft and Bredero. However, pioneering studies for the late eighteenth century (De Haas, 2014; De Leeuwe, 2003; Groot, 2011;

1 Based at the University of Amsterdam, the ONSTAGE project is an ongoing team effort by various contributors. The editorial board currently consists of editor-in-chief Frans R. E. Blom, editor Rob van der Zalm and programmers Harm Nijboer and Ivan Kisjes. The online version is available at http://www.vondel.humanities.uva.nl/onstage/. 
Ruitenbeek, 2002) already indicated what recent studies based on the ONSTAGE data system also demonstrate for the Schouwburg's entire early modern history: import drama plays from European theatre traditions dominated Amsterdam's play lists, the Schouwburg's directors showing a keen eye for changing fashions. Drama plays from the English stage were imported first (among others, some immensely popular revenge tragedies by Kydd and Shakespeare), some of which remained popular in the repertory of the Schouwburg for more than a century. During the mid-seventeenth century, the theatre enhanced its repertory with an amazing sequence of approximately 6o plays from Spain's great Siglo de Oro tradition. Lope de Vega paved the way in the 1640s, soon followed by playwrights like Calderón, Montalván, Amescua and many others (Blom, 2019). Some of these were hits until the end of the eighteenth century. By 1670 they were supplemented by a new vogue, represented by over a hundred French-classicist drama plays from Paris (Corneille, Racine), and also by an almost industrial adoption of Molière's comedies, dispensing with a great part of the traditional Dutch genre-farces. French plays kept dominating the play lists until well into the eighteenth century when the audiences experienced another change of taste in the form of bourgeois drama imported from Germany and Denmark. About 25 plays were by Kotzebue alone, with the people's favourite, Menschenhaat en berouw (the Dutch translation of Menschenhaß und Reue), brought to the Amsterdam stage in one hundred and fifty performances over a period of a century.

With the financial accounts, the ONSTAGE data system also allows for detailed research into the theatre's entrepreneurship, relating the history of the theatre to insights and methods in cultural economics and business history

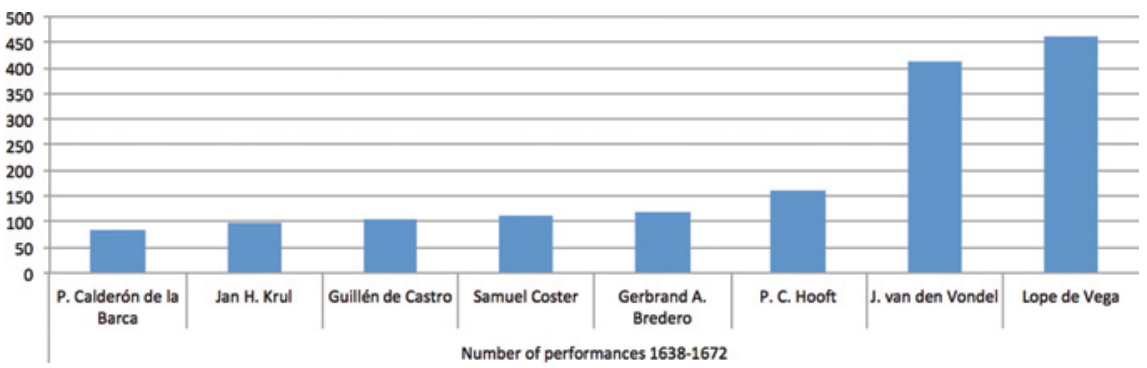

FIGURE 1 Cumulative Schouwburg-performances per playwright in the theatre's first decades, showing that the import plays by the Spanish playwright Lope de Vega surpassed in performance frequencies the plays by Amsterdam's prime domestic author Joost van den Vondel.

BASED ON ONSTAGE. SEE JAUTZE, FRANCÉS, \& BLOM, 2016; SEE ALSO BLOM \& VAN MARION, 2017 
(Gras, Franses, Van Vliet, \& Pratasik, 2011). Throughout its history, the Schouwburg's directors seemingly put economic considerations first, but overall they showed a remarkable flair for cultural entrepreneurship, too, protecting the theatre's market position through a judicious repertory mix of box office stalwarts and new productions, introducing new forms of entertainment, updating stagings, and renovating the theatre and its equipment to suit changing tastes and audiences. Financial accounts in the longue durée, as provided in ONSTAGE, reflect the theatre's management - both its policy of success consolidation and the effects of bold artistic innovations such as, for example, the highly controversial introduction of female actors to the stage.

Developed as a research instrument in the first place, ONSTAGE aims at bringing archival sources on performances and revenues into the heart of the University of Amsterdam's research on the artistic and economic history of the Schouwburg. ONSTAGE is supported by the Faculty's Priority Research program CREATE: Creative Amsterdam, an E-humanities perspective (see: http:// www.create.humanities.uva.nl). Moreover, ONSTAGE is a key tool for the NWO funded research program Golden Agents: Creative Industries and the Making of the Dutch Golden Age, which aims at developing a digital research infrastructure enabling interaction between various heterogeneous databases such as ONSTAGE (see https://www.goldenagents.org/). Internationally, ONSTAGE is affiliated with other European theatre database initiatives aiming to bring Europe's theatre history into a new phase. Using digitized archival sources, researchers ask fresh, more probing questions and combine the insights drawn from play texts, policy documents and theatre accounts with visual materials into a virtual revival of the historical stage. The pioneering Comédie-Française Registers Project (MIт/Sorbonne/Nanterre, at https://www.cfregisters.org/en/), started in 2007 , features a similar data system. Efforts are well underway to disclose London theatre archives in The London Stage database project (Burkert, 2017; available at http://www.eighteenthcenturydrama.amdigital.co.uk/ LondonStage/Database).

2. OnSTAge Data: Provenance

- ONSTAGE deposited at DANS - Dor:https://www.doi.org/10.17026/dans $-\mathrm{Z} 37-2 \mathrm{db} 7$

- Public interface - URL: http://www.vondel.humanities.uva.nl/onstage/

- Temporal coverage: $1638-2020$, continuing 


\subsection{Data Prior to 1814}

Covering the Amsterdam Schouwburg's theatre history from 1638 up to the present, ONSTAGE's data derive from different archival sources. First, the Amsterdam City Archives hold an important part of the theatre's early modern account books. They are part of the City Orphanage Archive Section, as the Municipal Orphanage owned the theatre; net profits were used to support the orphan children. The inventory number for the Schouwburg documents is Stadsarchief Amsterdam, inv. nr. 367.A: Archief van het Burgerweeshuis: oud archief, section 1.2.3.2, numbers 425-441, accessible at https://archief.amster dam/inventarissen/details/367.A. By now, all pages of the various account books are digitally accessible through the City Archives web portal (as demonstrated in Figure 2). Later copies of the Schouwburg account books, dating from the eighteenth century, are kept in the Huydekoper Family Archives at the Utrechts Archief (inv. nr. 67, especially nos. 318 en 319 'Lijsten en aantekeningen

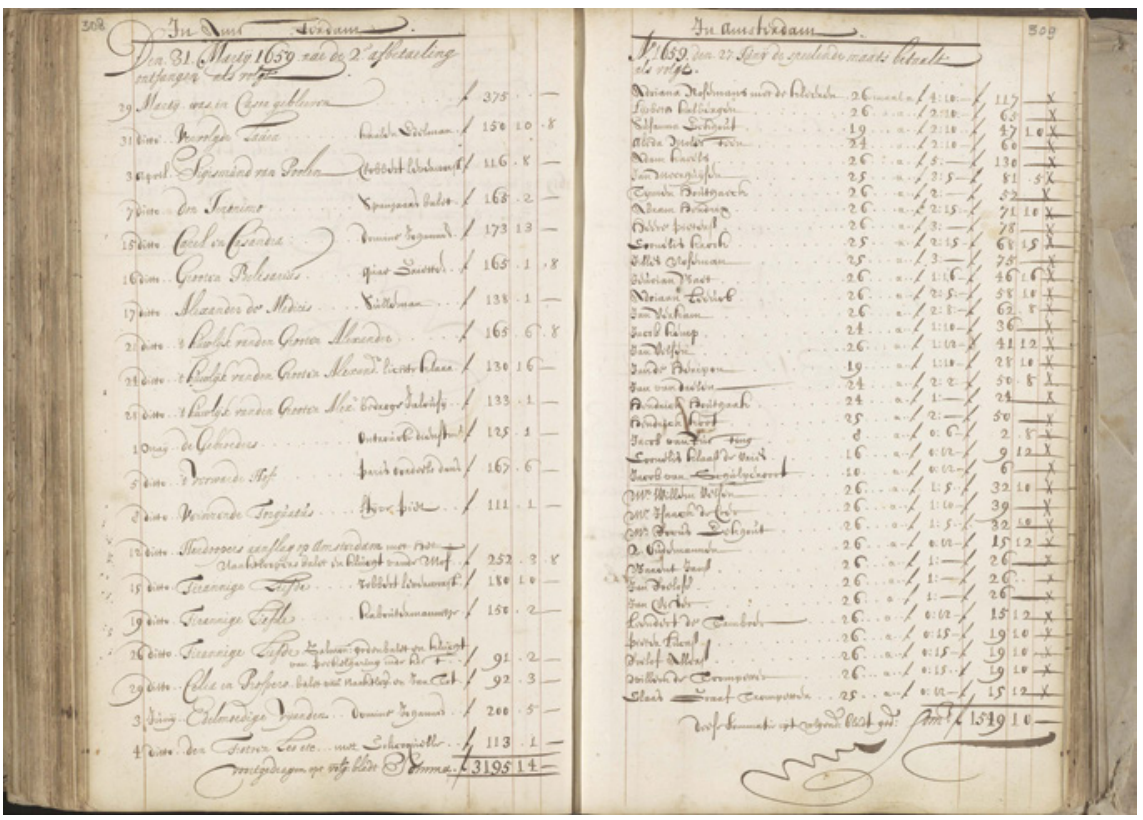

FIGURE 2 Account books of the Amsterdam Schouwburg, season 1658-1659, 31 March - 4 June.

STADSARCHIEF AMSTERDAM, INV. NR. 367.A: ARCHIEF VAN HET BURGERWEESHUIS: OUD ARCHIEF, SECTION 1.2.3.2, NUMBER 425, FOL. 308. RETRIEVED FROM HTTPS://ARCHIEF.AMSTERDAM/INVENTARISSEN/ SCANS/367.A/1.2.3.137.1.1/START/140/LIMIT/10/HIGHLIGHT/5 
betreffende de inkomsten en uitgaven van de Schouwburg over de jaren 16371741). In the past, transcripts of the early modern data have been published in book volumes (De Haas, 2001; Geesink \& Oey-De Vita, 1983). For the years 1772 to 1814 , ONSTAGE integrates similar data on performances as collected but unpublished by Bennie Pratisek (and revised by Anna de Haas), augmenting the existing archival data on revenues.

\subsection{Data After 1814}

After the French period in the Netherlands, the Schouwburg was detached from the City Orphanage's supervision, becoming an autonomous cultural institution. As a consequence, the administration of programming and revenues changed, and the ONSTAGE data accordingly derives from different sources from 1814 on. In her University of Amsterdam PhD thesis Kijkcijfers on the early nineteenth-century Schouwburg, Hennie Ruitenbeek (2002) collected the data of performances and revenues from the Schouwburg archief section in the Stadsarchief Amsterdam (inv. nr. 267, accessible on https://archief.amster dam/inventarissen/details/267) for the period 1814-1841, as part of her audience ratings research. For this period, some account books have been preserved (1821-1830), but revenue information is not complete. Data for the years 1841 to 1871 could not be traced in any administrative records; the ONSTAGE data is therefore based on the collection of programs and playbills kept in the Special Collections of the University of Amsterdam (accessible on http:// dpc.uba.uva.nl/inventarissen/ubainv548). Partly, these printed sources derive from the theatre's archive so that, for some years, they may include handwritten information on revenues per performance. Unlike the surviving information for the years 1638 to 1814 , however, the revenues have no structural presence in the data sources. As for the years 1871 to 1938 , ONSTAGE's data derive from announcements and advertisements published in the Dutch newspapers Algemeen Handelsblad ('Concert- en Tooneelnieuws' / 'Schouwburgen') and De Telegraaf ('Kunstagenda'), all searchable through the Delpher Dutch newspaper-interface at www.delpher.nl. In the performance announcements, of course, data on revenues are completely lacking.

Beginning with 1938, ONSTAGE includes information on revenues again, as these data derive from the Schouwburg archives that are kept in the Amsterdam City Archives. For the period from 1938 to 1944, the relevant Schouwburg archival sources are kept in the Amsterdam City Archives: Bibliotheek (15030): Toegangsnr. 15005 Inventarisnr. 1330/1332/1334; Amsterdam City Archives: 5479/69, 70, 73, 74, 76-79, 81, 82, 114, 119-121: 'Speelplannen en recettes' (not yet digitized). And the relevant Schouwburg archives dating from after the Second World War (1945) - (2003) are kept in the Archive of the Amsterdam City Theatre (Amsterdam City Archives inventory numbers 267.A and 30037 
TABLE 1 ONSTAGE data coverage

\begin{tabular}{lll} 
ONSTAGE data coverage & annual play lists & revenues \\
\hline $1638-1814$ & complete & complete \\
$1814-1841$ & complete & partly \\
$1841-1938$ & complete & absent \\
1938 -present & complete & complete
\end{tabular}

('Recettestaten (maandrapportages van de voorstellingen, bezoekersaantallen/inkomsten))'. Data from the most recent period $\left(2003^{-2016)}\right.$ is based on programs, partly digitized, in the Archive of the Amsterdam City Theatre, which is today's Schouwburg.

\section{Various Data Natures}

Incorporating data from the longue durée of almost four centuries of theatre history, ONSTAGE is complete for the dataset on performances by date, meaning that without any hiatus a play calendar can be reconstructed of 400 years of performances. For revenues, the archival sources as generated by the Schouwburg give structural information. However, for some periods those records are missing and ONSTAGE, as a result, builds on performance data from public sources, like newspaper announcements or programs. The cases where data on performance revenues are missing should, of course, be paid attention to in statistics that use these figures as proxies for quantifying performance attendances.

Another caveat to the quantification of revenues is that the amount of money brought in per performance comprises admission fees for both the main play and the subsidiary act(s) included as minor parts of the show. As those subsidiary pieces, like farces and ballets, were also included in the Schouwburg's public announcements, there is a theoretical possibility that people in the audience were not drawn to the main piece in the first place. When discussing the popularity of a play, therefore, revenues should be used with caution.

Thirdly, change was a constant feature of the organization and operating of the Schouwburg. For one, in 1814 ties with the City's Orphanage were cut and the theatre became an autonomous art institution in the city. Both in art and business, the theatre's aims and management may well have been affected by such a rupture, as well as the repertory and the target audiences. 


\section{HOLLANDSCHE SCHOUWBURG \\ DE KONINKLYKE TOONEELISTEN VAN DEN AMSTERDAMSCHEN SCHOUWBURG, zullen vertoonen op \\ MAANDAG, den' 21 ften September, 1818 .

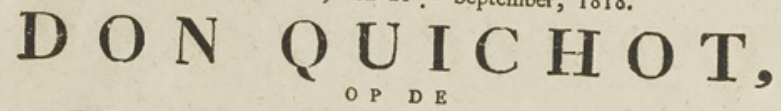

B R UILOFT VA N KAMACHO; OORSPRONKELTK BLTSPEL met ZANG on DANS

I N DRIE BE D R Y VEN. Door den Heer P. LANGENDYK.

Acteurs: P J. Snoeck, Van Hulst, Henke, Weidman, Westerman, Rofenveldt, Majofski, Oortman, Beynink, Oberg, enz.

Actrices: Jelgerhuis, M. Snoeak geb. Grotta, Karels, enz.

$$
\text { En na betzelve. }
$$

\section{$P A N T A L O N \underset{O_{F}}{R E N T E N I E R,}$}

ARLEQUIN IN HET LAND DER DWERGEN;

GROOT BALIET PANTOMIME.

Door Wylen den Heer J. VAx WELL.

En op nieuw gemonteerd door den Heer A. vAX HAMMB.

Muayk door den Heer F. MULLER.

$T$ en ZES URE op het Tooneel.

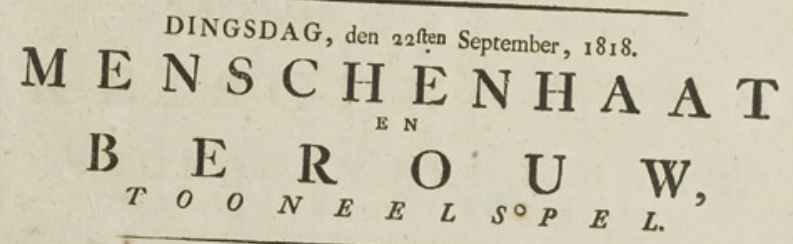

NB. De Plaatfen zyn by den Kastelein, in den Schouwburg, te befpre-
ken, van des voormiddags ten mits betalende 2 Stuivers voor ieder tot des namiddags ten 3 uren,

Te Amfterdam, tet Drukkerye van $\triangle B R \triangle B A M$ MARS, Bockverkooper in de Nes, $N^{\circ} .43$.

FIGURE 3 Schouwburg poster for September 21, 1818 (Amsterdam's Kermisweek), announcing Pieter Langendijk's Don Quichot and August von Kotzebue's Menschenhaat en berouw, but no information on revenues.

STADSARCHIEF AMSTERDAM, SCHOUWBURGARCHIEF. RETRIEVED FROM

HTTPS://ARCHIEF.AMSTERDAM/INVENTARISSEN/SCANS/267/1.3.1.13/

START/10/LIMIT/10/HIGHLIGHT/6 
When studying popularity, numbers by themselves may be deceptive and circumstantial factors should not be neglected. On the other hand, however, changing performance patterns may indicate a deliberate change of artistic course.

Also, it should be taken into account that the Schouwburg was a monopolistic home theatre in the early modern period, exclusively available to its own professional company of actors and directors, whereas in later times, visiting groups were welcome to stage their performances there. This, of course, means that the Schouwburg changed from a repertory-driven theatre in early modern times to a performance hall in the modern sense.

Finally, it should be noted that even though the Schouwburg was the first and most important theatre, the theatre landscape in Amsterdam has changed constantly. By the end of the eighteenth century, for one, the city opened up to rivalling theatres like the French Theatre and the German Theatre. And today, of course, the Amsterdam Schouwburg is surrounded by several theatre venues. When focusing on popularity in the Schouwburg, one should be aware of the venue's position and its operations as a monopolistic theatre or in an artistically and commercially competitive setting.

\section{Enriched Data}

With the performance data in a complete dataset, ONSTAGE aims at identifying all entries and connecting various performances of the same play to one standard title. Entry data for the same play may differ considerably in the archival sources. The famous seventeenth-century revenge tragedy of Aran en Titus occurs in the data as 'Titus' or 'Titus Andronicus' or 'Titus Andronikus' or as 'Titus en Aran'. Although source variants have been retained in the data system, they all link and group under one standard title, based on the first printed edition of the play following our scholarly works of reference.

The next enrichment feature in ONSTAGE is that all plays have been identified by author. The several variants of Aran en Titus thus not only connect to a standard title, but to the work's original playwright, Jan Vos, as well, enabling author-focused research and data grouping by playwright.

The Amsterdam Schouwburg has always been an internationally oriented theatre. From its very beginnings, performances were not only domestic productions by Amsterdam playwrights, but also international hits drawn, in translation and adaptation, from various European stage traditions. Spanish theatre, for example, had a massive impact on the theatre's programming in the seventeenth and eighteenth century. In order to highlight the function 


\section{ONSTAGE}

Online Datasystem of Theatre in Amsterdam from the Golden Age to Today

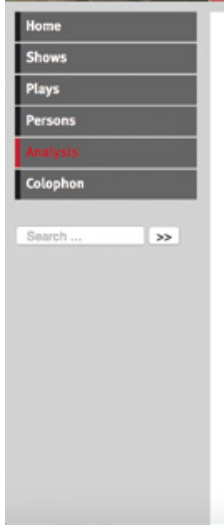

\section{The $\mathbf{5 0}$ most popular plays ranked first in the program between 1638 and 1666}

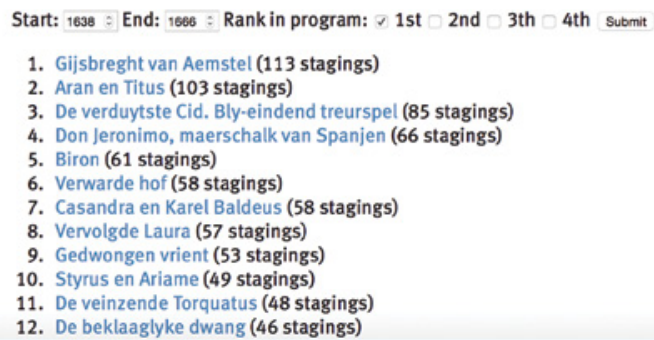

FIGURE 4 The Schouwburg's twelve most frequently staged repertory plays over the period 1638-1666, featuring domestic creations such as Joost van den Vondel's Gijsbreght, Brandt's Veinzende Torquatus and Struys's Styrus en Ariame, among foreign plays from England (Jan Vos' Aran en Titus, the anonymous Don Jeronimo and Hendrick Roelandt's Biron), France (Heemskerck's Cid) and, most of all, from Spain (L. de Fuyter's Verwarde Hof, Theodore Rodenburgh's Casandra, Adam Karelsz van Germez's Vervolgde Laura, Isaac Vos's Gedwongen Vrient and Beklaaglyke dwang)

of the Schouwburg as an international hub, ONSTAGE also identifies the plays' foreign provenances. For a revenge tragedy like Jan Vos's Aran en Titus, this means that there is a reference, within the general entry for Aran en Titus, to Shakespeare's Titus Andronicus, while, for example, the early modern superhit of Veranderlijk Geval (boasting a performance history of almost two centuries in Amsterdam) has been identified in the data collection as a Spanish play and linked to its original version, Las Mudanzas de la Fortuna by Cristóbal de Monroy y Silva. Moreover, when popular plays from the Amsterdam repertory crossed borders and were translated in other vernaculars, these transmissions, too, have been added. That's why, for example, the general entry of Heemskerck's play De verduytste Cid (1641) not only refers to its source of Pierre Corneille Le Cid (1637) but also links to the German adaptation Die Sinnreiche Tragi-Comoedia, genannt Cid (1650), which the Hamburg writer Georg Greflinger based on the Dutch play. With these designations, ONSTAGE facilitates data research into the vast and ever-changing import patterns of 


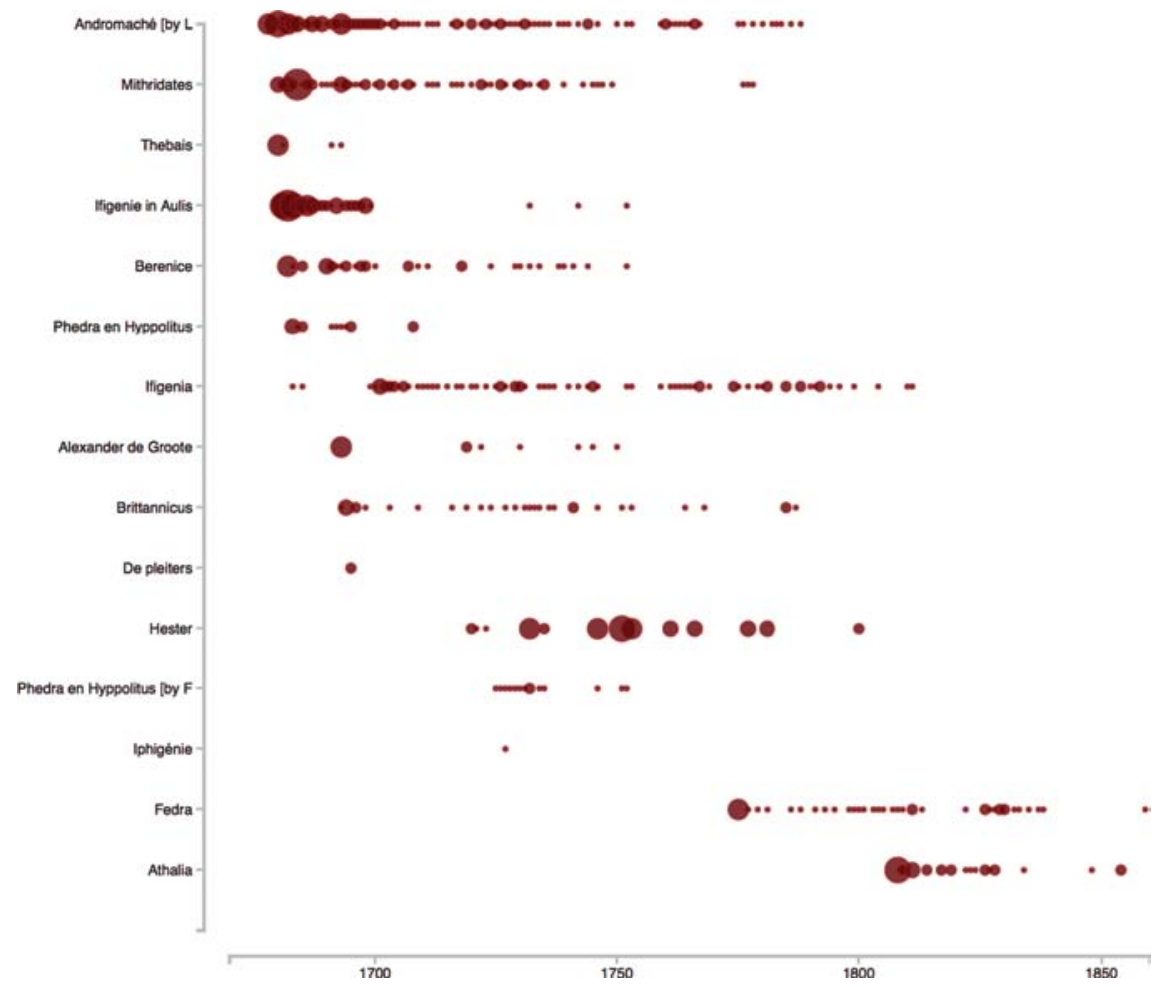

FIGURE 5 Two hundred years of performance history and staging frequencies of the French playwright Jean Racine in the Amsterdam Schouwburg (1670-1870). BASED ON ONSTAGE

European plays in the Schouwburg and Amsterdam's favourite foreign playwrights. Moreover, the international identifications will allow for data integration with similar databases for other European theatre metropoles, such as the Comédie-Française Registers Project or The London Stage Database Project, in the future.

\section{Data Model and Data Access}

ONSTAGE is a relational database, meaning that the data is organized in tables consisting of columns and rows. Each row in these tables has a column marked by a unique identifier (a key) that allows a record in one table to be linked to a record in another table. Organizing data in multiple tables is done to facilitate 


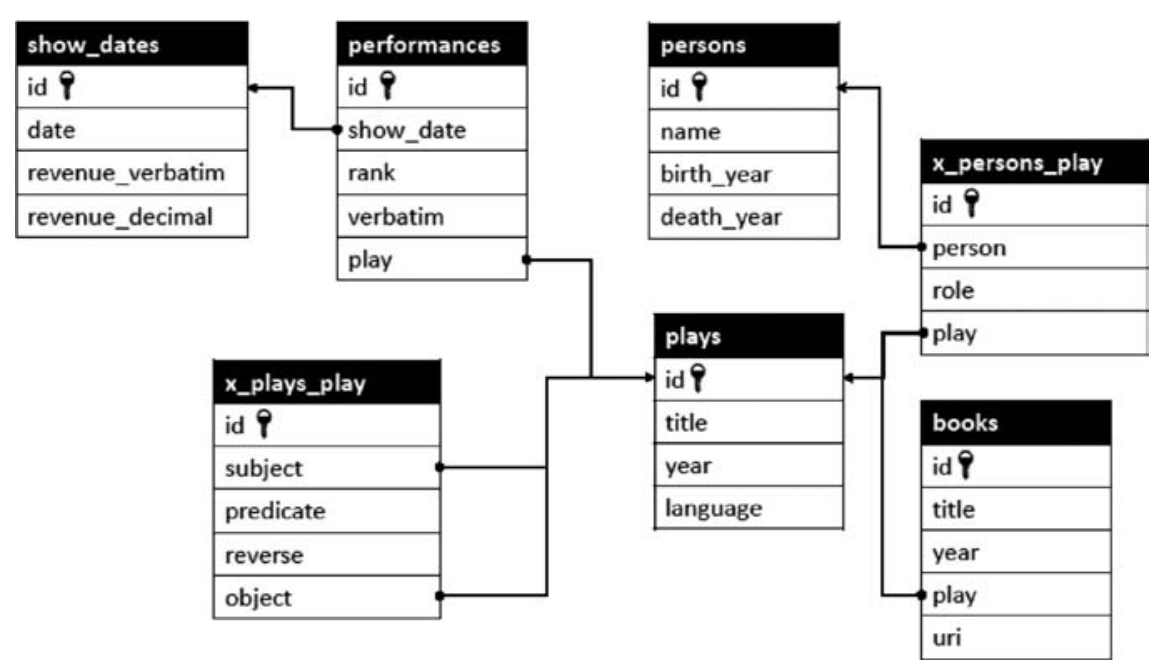

FIGURE 6 The ONSTAGE data model.

the storage and querying of data that has one-to-many and many-to-many relations. A theatre program, for instance, can consist of one, two or even more plays being performed at the same date. The onstAGE data model, therefore, uses a 'show_dates' table that defines the shows and dates that are covered by ONSTAGE. The 'performances' table holds the separate performances that are connected to a single show/date by the 'show_date' column. The complete model is shown in Figure 6.

Most of the model will be self-evident, but two things might need further clarification. The performances table holds a column labelled 'verbatim,' which contains the description of the performed work as found in the source. We have retained this information for two reasons: 1) users might for good reasons want to know what exactly was written in the original document, to be able to check whether it has been correctly identified; and 2) sometimes a verbatim entry cannot be linked to a specific play because it is too generic or because it is unclear which play it refers to.

The second feature that needs some clarification is the 'x_plays_play' table in which relations between plays are stored (e.g. one play as a translation of another). The table uses a subject-predicate-object grammar to make such statements. But since subject and object are in this case of the same type, the reverse of the predicate is also made explicit.

One needs to know some SQL to effectively query the data in its native format. For less technically savvy researchers, the data is also available on the 
ONSTAGE website. The online site not only allows users to browse and search the data, but it also provides tools to visualize trends and patterns in the programming of the Schouwburg. Less visible but equally important is the website's access to the data in a machine-readable format (RDFa) that can be used by search engines and other data harvesters.

\section{Ambitions}

As an ever-expanding dataset on the Schouwburg, ONSTAGE's next step is to supplement the data on performances and revenues with the data on operating costs. Continuous data on the theatre's expenses are available in the account books from 1638 to 1814 . This will enable researchers to compare the theatre's income with the archival data on expenses for actors' salaries, stage props and other production costs. In the longer term, ONSTAGE also aims to incorporate other archival sources on the Schouwburg. The Amsterdam City Archives hold parts of the theatre's administration documents on management and policy, and on casting.

Secondly, ONSTAGE is developing a linked data system. As most of the archival sources have been digitized and made publicly available on the internet, links will be established between ONSTAGE's data records and the original documents. Moreover, with the impressive collection of historical theatre play textbooks kept in the University of Amsterdam's Special Collections, each play in the ONSTAGE dataset will be linked to entries in digital bibliographies, such as the Short Title Catalogue Netherlands, which holds the bibliographical descriptions of all plays in all different editions throughout time, and to the scans of the play textbooks in Google Books. Similarly, the plays will also be connected to digital text editions in the Digitale Bibliotheek voor de Nederlandse Letteren and to CENETON, the digital text collection of Netherlandish Drama. Finally, for visual representations of plays and performances, ONSTAGE will also connect to images and other visual data of performances in digitized art historical collections, such as the online Rijksstudio of the Rijksmuseum or the databases maintained by the RKD - Netherlands Institute for Art History.

Thirdly, the website does not yet allow users to browse and search the data, using tools to visualize trends and patterns in the programming of the Schouwburg. Therefore, ONSTAGE wants to grow from a research instrument, mainly, into a public and user-friendly platform open to anyone interested in theatre. Interfaces will facilitate easy access to the data, and allow for data extractions and visualizations. In doing so, ONSTAGE ensures its centre stage position both in international academic research and among a wider audience. 


\section{References}

Blom, F. R. E., \& Van Marion, O. (2017). Lope de Vega and the conquest of Spanish theater in the Netherlands. Anuario Lope de Vega. Texto, literatura, cultura, 23, 155-177. Dor: https://www.doi.org/10.5565/rev/anuariolopedevega.194.

Blom, F. R. E. (2019). Enemy treasures: the making and marketing of Spanish Comedia in the Amsterdam Schouwburg. In Y. Rodríguez Pérez (Ed.), Literary hispanophobia and hispanophilia in Britain and the Low Countries (1550-1850). Amsterdam: Amsterdam University Press, 115-144. Retrieved from: https://www.jstor.org/stable/ j.ctvvh86ft.8.

Burkert, M. (2017). Recovering the London Stage Information Bank: Lessons from an early humanities computing project. Digital Humanities Quarterly, n(3). Retrieved from http://www.digitalhumanities.org/dhq/vol/11/3/000321/000321.html.

De Haas, A. S. (2001). Het repertoire van de Amsterdamse Schouwburg 1700-1772. Maastricht: Shaker Publishing.

De Haas, A. (2014). Theatrale zelfmoord: De eigenhandige dood op het Nederlandse toneel 1670-1780. Hilversum: Uitgeverij Verloren.

De Leeuwe, H. H. J. (2003). De Amsterdamse schouwburg in 1795. Het eerste jaar der Bataafse vrijheid. Zutphen: Walburg Pers.

Geesink, M., \& Oey-De Vita, E. (1983). Academie en Schouwburg. Amsterdams toneelrepertoire 1617-1665. Amsterdam: Huis aan de Drie Grachten.

Gras, H., Franses, P., Van Vliet, H., \& Pratasik, B. (2011). Theatre as a prison of longue durée. Bern: Peter Lang.

Groot, K. E. (2011) Geliefd en gevreesd. Duits toneel in Nederland rond 180o. Hilversum: Uitgeverij Verloren.

Jautze, K. J., Francés, L. Á., \& Blom, F. (2016). Spaans theater in de Amsterdamse Schouwburg (1638-1672). Kwantitatieve en kwalitatieve analyse van de creatieve industrie van het vertalen. De Zeventiende Eeuw. Cultuur in de Nederlanden in interdisciplinair perspectief, 32(1), 12-39. Dor: http://www.doi.org/10.18352/dze.1000o.

Ruitenbeek, H. (2002) Kijkcïfers: De Amsterdamse schouwburg 1814-1841. Hilversum: Uitgeverij Verloren. 